\title{
GENOCIDE: A COMMENTARY ON THE CONVENTION
}

DuRING twelve years of Nazi rule the paranoia which obsessed large parts of the German population found partial expression in the mass-murder of racial and ethnic groups. ${ }^{1}$ This was no spasmodic outburst, but an official policy, fomented, rationalized, ${ }^{2}$ and legalized ${ }^{3}$ by the Nazi State. While an apathetic world looked on, planned butchery of "racially inferior" groups reached such extent that even the highly efficient Nazis were unable to conceal the evidence of their crime. ${ }^{4}$

Despite the appalling nature and scope of these offenses, the International Military Tribunal established by the victorious powers ${ }^{\sigma}$ at Nürnberg found insufficient basis in existing international law to convict the defendants for racial policies carried out prior to 1939. Over the objection that the crimes for which the defendants were tried were ex post facto formulations, ${ }^{0}$ the Tribunal founded its jurisdiction on Germany's violation of numerous treaties 7 -

1. The Nazis killed an estimated 6,000,000 Jews. OfFice of United States Counser for Prosecution of Axis Crininality, Nazi Conspiracy and Aggression (Opinion and Judgment of the International Military Tribunal) 82 (1947). See, generally, LEMKIN, Axis Rule in Occupied Europe (1944); The Black Book (1946); THe Black Book of Polish Jewry (Apenszlak ed. 1943) ; Hitler's Ten Year War on the Jews (1943); The Black Book of Poland (1942).

2. "Any defeat can become the father of a later victory . . . . as long as the blood remains preserved in purity. . . . All really important symptoms of decay of the pre-War time uitinately go back to racial causes." Hitrer, Mein KAMipF 452 (Reynal \& Hitchcock ed. 1939).

3. The Nazi policies are analyzed and documented in LENsin, op. cit. stipra note 1. For the State policy of deliberate starvation of "racially inferior" groups, see Srun, STAltvation over Europe (Made in Germany) : A Docunsented Record (1943).

4. Following the Russian victory at Stalingrad the Germans became mindful of the need of concealing evidence of their crimes should they be defeated, and began exhuming and cremating bodies previously buried in mass graves. See generally, TuL BLACK Book $243,310-12,389,409-10$ (1946).

5. At London on August 8, 1945 the governments of great Britain, the United States, France, and the Soviet Union entered into an Agreement establishing the Tribunal for trial of war criminals and a Charter defining the Tribunal's jurisdiction and functions. The following governments subsequently adhered to the Agreement: Australia, Belgium, Czechoslovakia, Denmark, Ethiopia, Greece, Haiti, Honduras, India, Luxemburg, the Netherlands, New Zealand, Norway, Panama, Paraguay, Poland, Urugutay, Venczucla, and Yugoslavia. The texts of the London Agreement and the Charter are printed in DEpartasent of State Publication No. 3080, pp. 420-8 (1949) and 19 Temp. L. Q. 160-8 (1945). Publicatron 3080 contains a verbatim record of the London Conference.

6. A storm of controversy accompanied the issue. Compare April, An Inquiry into the Jurisdictional Basis for the Nuremberg War Crimes Trial, 30 MrNN. L. Rev. 313 (1946) and Professor Rheinstein's Review of Glueck, The Nuremberg Trial ANd AgGRESSIVE WAR (1946), 14 U. OF CHI. L. REv. 319 (1947), with Goodhart, The Legality of the Nuremberg Trials, 58 JuRid. Rev. 1 (1946) and Meltzer, A Note on Some Aspects of the Nuremberg Debate, 14 U. of CHI. L. Rev. 455 (1947). An analysis of the traditional legal prohibition against retroactive punishment is found in Hall, Nulla Pocna Sinc Lege, 47 Y ALE L. J. 165 (1937).

7. In addition to the Kellogg-Briand Pact of 1928, the Tribunal citcd, inter alia, the Hague Conventions of 1899 and 1907, numerous articles of the Treaty of Versailles, and the 1925 Locarno Treaties of Mutual Guarantee. OfFice of United Stutes CHilef of 
notably the Kellogg-Briand Pact- ${ }^{8}$ and convicted the offenders of the crime of planning and waging aggressive war. ${ }^{9}$ The Court held, however, that it had no jurisdiction over crimes against humanity unless the acts complained of were accomplished "in execution of, or in connection with," aggressive war, and that it could find no such connection with German pogroms consummated before the war began. ${ }^{10}$ Only group extermination carried on during the war was held punishable.

Conscious of this legal shortcoming of the Nürnberg trial, the United Nations General Assembly unanimousiy adopted ${ }^{11}$ a Convention ${ }^{12}$ on Genocide. ${ }^{13}$

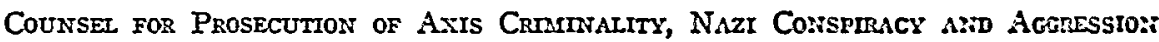
(Opinion and Judgment of the International Military Tribunal) 46-54 (1947).

8. Officially called the General Treaty for the Renunciation of War, the Pact, made in 1928, was binding on almost all the nations of the world, including Germany, Italy, and Japan. Under it the contracting parties renounced war as an instrument of national policy and pledged themselves to seek solution to international disputes by pacific means only.

9. For an analysis of the crime of aggressive war, viewed as a development of "international common law," see Walkinshaw, The Nuremberg and Tolyo Trials: Another Step toward International Justice, 35 A.B.A.J. 299 (1949). For general comments on the trial see Jessup, The Crime of Aggression and the Future of Intemational Low, 62 PoL. Scr. Q. 1 (1947) and Wechsler, The Issues of the Nuremberg Trial, 62 PoL Ser. Q. 11 (1947).

10. On this point the Tribunal confined itself to the following statement: "The Tribunal is of the opinion that revolting and horrible as many of these crimes were, it has not been satisfactorily proved that they were done in execution of, or in connection with, any such crime [crime of aggressive war]. The Tribunal therefore cannot make a general declaration that the acts before 1939 were crimes against humanity within the meaning of the [London] Charter, but from the beginning of the war in 1939 war crimes were committed on a vast scale, which were also crimes against humanity; and insofar as the inhumane acts charged in the indictment, and committed after the beginning of the war, did not constitute war crimes, they were all committed in execution of, or in conneetion with, the aggressive war, and therefore constituted crimes against humanity." OFFICE of United States Chief of Counsel for Prosecution of Axis Crusmmatrin, Nazi Co:iSPIRACY AND AGGRESSION (Opinion and Judgment of the International Mfilitary Tribunal) 84 (1947).

Since by its judgment the Nürnberg Court held individual participants liable for a nation's treaty violations-a step unprecedented in modern international law-it would have required no further stretch of legal imagination also to hold them liable for crimes of group extermination committed before 1939. The reasons compelling the Court to make this distinction are not clear.

11. There were no abstentions. See Verbatim Record of the Third Session, One Hundred and Seventy Eighth Meeting, of the United Nations General Assembly, Ducument No. A/PV 179, at 70 (Dec. 9, 1948) (mimeographed). The United Kingdom's vote was entered subject to possible reservations with respect to the right to grant asylum and to further study of the Convention as it relates to British criminal law. Id. at 22 . The Verbatim Record will hereafter be cited: Journal of the General Assembly, No.-

12. The Convention text and two related resolutions passed the same day are printed as an Appendix to this Comment. They are taken from the Journal of the General Assembly, No. A/PV 178, at 2-5a (Dec. 9, 1948).

The text of the Convention may also be found in Departsiesti of Stute Punlication No. 3416 (1949) ; 5 United Nations Bulletin 1012-5 (1948); and 35 A. B. A. J. 57-8 (1949).

13. Coined by Professor Raphael Lemkin, the word is constructed from the Greels 
The Convention differs from other international proclamations, such as the Universal Declaration of Human Rights, ${ }^{14}$ which have made normative pronouncements on moral principles concerning the economic, social, and cultural rights of man. ${ }^{15}$. Focusing attention on the offender and his apprehension, it contemplates immediate employment of domestic criminal sanctions against him, ${ }^{16}$ some measures of international control and cooperation, ${ }^{17}$ and eventual exercise of international criminal jurisdiction by a permanent world court. ${ }^{18}$ Under the Convention the nations of the civilized world recognize their responsibility to take individual and collective action in stamping out mass scale destruction of groups. ${ }^{10}$ If the agreement is ratified by twenty States, ${ }^{20}$ genocide will take its place beside piracy, traffic in women and children, and slavery, as an internationally recognized crime.

\section{The Crime}

The Convention defines genocide as the intentional destruction of any national, ethnical, racial or religious group. ${ }^{21}$ It proscribes killing members of the group, causing them serious physical or mental harm, imposing conditions of life calculated to bring about their physical destruction, taking mensures intended to prevent births within the group, and transferring children from one group to another. ${ }^{22}$ Not only is the act of genocide itself punishable, but similarly condemned are acts constituting direct, public incitement to genocide, attempts to commit the crime, or complicity in it. ${ }^{23}$ Constitutionally responsible rulers, public officials, and private individuals are all subject to prosecu- tion. ${ }^{24}$

As finally adopted, the Convention definition of the crime has more limited

word genos, meaning "race" or "tribe," and the Latin word cide, meaning "killing." Sec discussion in LEMKIN, op. cit. supra note 1, at 79-80.

14. The Declaration, as adopted, is printed in Departarent of State Publication No. 3416 (1949). The Declaration is a mere statement of principles without the force of a treaty, but it may have the influence of a great state paper, subscribed to by forty nations of the world. It is contemplated that an enforcing covenant subsequently will be drafted.

15. For past efforts to protect human rights through international law see the reference collected in Robinson, Hunan Rights and Fundanental, Freedoms in tue CirastTER OF THE UNITED NaTTONS 1-6, nn.1-11a (1946).

16. See Convention on Genocide Art. V. The Convention will hereafter be cited by article only.

17. Articles VII, VIII, and IX.

18. Article VI; and Appendix, infra, Resolution Relating to the Study by the Intcrnutional Lazo Conmission of the Question of an International Criminal Jurisdiction.

19. See Preamble and Article I:

20. Article XIII.

21. Article II.

22. Ibid.

23. Article III.

24. Article IV. The Convention does away with the so-called "Act of State" doctrine Under the Convention, the acts of individual offenders would subject them to criminal 
scope than as first proposed. An original draft provision extending protection to political groups was, in the interest of quicker unanimity, eliminated.:-3 Moreover, the crime includes only biological, and physical genocide. ${ }^{\Omega}$ Original drafts ${ }^{27}$ made reference to "cultural" genocide, i.c., acts aimed at destruction of libraries, museums, schools, historical monuments, and religious edifices, or the suppression of language or printing media of a particular group. But the United States successfully urged exclusion of this form of genocide. The American delegation expressed the belief that the Convention should proscribe only acts directed toward physical destruction of the designated groups themselves, and that acts tending toward the destruction of their institutions should be dealt with in a subsequent treaty for the protection of minorities. ${ }^{2 s}$

In making "direct and public incitement to commit genocide" a crime, 9 the Convention is again more limited than the substance of previous drafts. The original Secretariat draft also made punishable "[a]ll forms of public propaganda tending by their systematic and hateful character to provoke genocide, or . . . make it appear as a necessary, legitimate or excusable act. . . ."28 Hearkening to the admonition of the United States that under American law speech may not be interfered with unless it constitutes "clear and present danger,"31 the drafting nations deleted the provision suppressing propaganda. Article III still makes "direct and public incitement" to genocide a crime, but the possibility of conflict between this provision and American constitutional guarantees of free speech is removed by Convention Article V, under which

responsibility, whether or not the State ratifies their misdeeds. Traditional nations of the "Act of State" doctrine are discussed in Fenwick, Inimsnatjo:iar LAW 212-13 (2d cd. 1934) ; see generally 1 Oppenerem, INTERNational LAW $\$ \$ 157-165$ b (7th ed., Lauterpacht, 1948).

25. The World Jewish Congress first recommended that political groups be excluded from the Convention's definition of genocide. The recommendation was made to obviate the delay in acceptance which might have been occasioned by differenees of opinion as to what constitutes a political group. See Prevention and Punishment of Genocide: Comments by Governments on the Draft Convention; Communieations from Non-governmental Organizations (Economic and Social Council Doc. E/623) 51 (Jan. 30, 1948) (mimeographed). Economic and Social Council documents will hereafter be cited: Economic and Social Council, Doc. No. - .

26. The various types of genocide are analyzed and discusscd in Lermm, of. cit. supra note 1, at $82-90$.

27. Economic and Social Council, Doc. No. E/623, at 9-10 (Jan. 30, 1943).

28. France joined the United States in this contention. See, generally, Economic and Social Council, Doc. No. E/623, at 11-13 (Jan. 30, 1948) ; see also the Government of India's statement in the United Nations, Journal of the General Assembly, No. A/PV 178, at 61 (Dec. 9, 1948). Great Britain favored the United States' view, id., No. A/PV 179, at 22 (Dec. 9, 1948). Russia, Venezuela, and Pakistan strongly favored inclusion of cultural genocide, however, $i d .$, No. A/PV 178, at 15-16, 23-36.

29. Article III.

30. Economic and Social Council, Doc. No. E/623, at 14 (Jan. 30, 1948).

31. Ibid. 
contracting States agree to enact effectuating legislation only in accordance with their respective constitutions. As the Convention is now constructed no person in the United States could be apprehended for incitement to genocide unless arresting officials met American constitutional free speech tests. ${ }^{\text {sy }}$

\section{ENFORCING THE CONVENTION}

The provisions for enforcement involve the most difficult problems and constitute the most significant aspect of the Convention. Not only are they tentative answers to the legal impotence of Nürnberg, but upon them depends the Convention's ultimate success as a device for application of positive criminal sanctions against genocide. If the Convention is to be something more than a proclamation of international law, the enforcement provisions must be made effective.

The Convention contemplates enforcement at both the domestic and international level. It envisages domestic enforcement by incorporation of the crime, with adequate penal sanctions, ${ }^{33}$ into national criminal codes, ${ }^{34}$ and in-

32. The limitations which the Constitution might impose on this clause of the Convention are indicated in the recent case of Terminiello v. Chicago, $69 \mathrm{~S}$. Ct. 894 (1949). Terminiello had made vituperative remarks vilifying Communists and "communist Jewish or Zionist Jews." A large, angry crowd gathered and demonstrated outside the auditorium. Following his speech, the speaker was convicted for disorderly conduct under a city ordinance interpreted by the trial court's charge as making punishable any speech which "stirs the public to anger, invites dispute, brings about . . . unrest, or creates a disturbance."

Without sanctioning Terminiello's remarks and without reaching the question of whether the speech was composed of "derisive, fighting words" under the prohibition of Chaplinsky v. New Hampshire, 315 U.S. 568, 573 (1942), a divided Supreme Court reversed the conviction on the ground that the ordinance as construed by the charge was unconstitutional. The Court went on to say: "[F] reedom of speech, though not absolute, ... is nevertheless protected against censorship or punishment, unless shown likcly to produce a clear and present danger of a serious substantive evil that rises far above public inconvenience, annoyance, or unrest." 69 S. Ct. 894, 895 (1949). The implications of the decision have yet to be explored.

Under the United States Constitution the free speech borderline seems presently to lie somewhere between speech which excites public annoyance or unrest (Terminiello $\mathrm{v}$. Chicago, supra) and "fighting words," Chaplinsky v. New Hampshire, 315 U.S. 568, 573 (1942), or words which create a "clear and present danger," Schencl: v. United States, 249 U.S. 47, 52 (1919).

A possible device for striking at irresponsible and malicious group defamation is the concept of group libel. Development of this concept, which has yet to be accepted, should by analogy aid prosecutions for incitement to genocide. As to the present state of the law of group libel, see Reisman, Democracy and Defamation, 42 CoL. L. REv. 727, 1085, 1282 (1942). But see State v. Klapprott, 127 N.J.L. 395, 22 A.2d 877 (1941) (group slander statute held unconstitutional).

33. Article V requires only that signatory States pass "necessary legislation to give effect" to the Convention's provisions, thus permitting each subscribing State to decide what criminal legislation is "necessary." But if other nations object that one of the contracting parties is not properly fulfilling its obligation to legislate, under Article IX they can bring the matter before the International Court of Justice.

34. Article V. 
ternational control through existing United Nations and International Court of Justice procedures. ${ }^{35}$ Future creation of a world criminal court having jurisdiction over the crime of genocide is as yet only suggested by the Convention, ${ }^{36}$ and is contingent upon future acceptance by such States as shall subscribe to a subsequent convention.

Domestic Enforcement. Under Article V, subscribing nations undertake to enact "in accordance with their respective constitutions" domestic criminal legislation to implement the objectives of the Convention. Jurisdiction of the offense would be confined to a territorial basis, ${ }^{37}$ with States extraditing fleeing offenders in accordance with their laws and treaties concurrently in force. ${ }^{.39}$ Genocide is not to be considered a political crime exempt from extradition. 00

Domestic enforcement would always be effective to suppress small-scale genocidal eruptions not sponsored by national governments. In these instances, the State, aided by legislation which makes attempts, conspiracies, and incitement punishable, could undertake measures to repress and punish the acts even in their initial stages.

Except in these rare instances, however, genocide would not be susceptible of punishment by domestic authority. Genocide, as distinguished from a series of individual crimes such as assault or murder, must involve the planned destruction of a group. To carry such a program to successful completion would almost necessarily require active or silent support of the State having territorial jurisdiction of the offense. 20 Either domestic law would be modified to give legal endorsement to the acts, ${ }^{41}$ or else the State would refuse to enforce existent law by failing judicially to characterize the acts as genocide or by completely ignoring their existence. Offending State leaders cannot be expected to punish themselves.

International Enforcencnt. In addition to enforcement at a national level, the Convention entrusts some measure of control over the crime to existing international institutions. The control, however, is the usual indirect international coercion upon States, and no international jurisdiction over individuals would be effected.20 Under Article VIII contracting States may call upon

35. Articles VIII, IX.

36. See note 18 sitpra.

37. Article VI. The original Secretariat draft would have permitted States to punish genocide "irrespective . . . of the place where the offence has becn committed." Economic and Social Council, Doc. No. E/623, at 16 (Jan. 30, 1948). This broad jurisdictional provision met the objection that charges of genocide against aliens might be used as a cloal: for political retribution. See comment of the United States, id. at 17.

38. Article VII.

39. Ibid. Many nations refuse to extradite political offenders.

40. It is difficult to conceive of a major, successful plan of genocide unless the ferpetrators were first to gain control of the State. From the time of the internecine massacres described in the Bible until the present, few reported instances of genocide have been accomplished without such control.

41. Germany, during the period of Nazi control, provides an example. See note 3 supra.

42. In this respect, the Convention would, for the present, continue traditional notions 
organs of the United Nations for prevention and suppression of genocide, and under Article IX they agree to refer disputes concerning the interpretation, application, or fulfillment of the Convention to the International Court of Justice. Only States would be entitled to bring action under either of these provisions, ${ }^{43}$ and only States could be the objects of sanctions.

Enforcement of the Convention at an international level depends chiefly upon the moral suasion which might be mustered by organs of the United Nations. Action in the General Assembly would be limited to discussion and recommendation. ${ }^{44}$ As a result, the Assembly could serve only as a sounding board for world opinion, a forum which could hear charges of alleged acts of genocide. Economic and Social Council action would likewise be narrowly confined. Though that Council could make studies and reports and set up investigative commissions, ${ }^{45}$ its function would be limited to gathering and supplying information and making recommendations. ${ }^{40}$

While the Security Council, theoretically at least, possesses coercive power to control genocide, ${ }^{47}$ the chances of the Council's employing more than economic and diplomatic sanctions are negligible. The Council could have a genocide question referred to it in two ways: a State might bring a genocide accusation directly to the Council under Convention Article VIII; or a State disputing the Convention's interpretation, application, or fulfillment might refer the matter to the Council from the International Court of Justice, as provided by Article $94(2)$ of the United Nations Charter. ${ }^{48}$ Following referral the Council might make recommendations, ${ }^{40}$ but plenary power could not be employed unless the Council found that the alleged acts threatened world peace. ${ }^{60}$ And even though the Council should find this kind of threat, each of the five na-

of international legal relationship, viz, that "International Law is a body of rules governing the relations of sovereign states between one another." 1 OPPENHEMT, INTERNATIONAL LAW $\$ 2$ (7th ed., Lauterpacht, 1948). The concept is attacked in Jessur, A MoDERN LAw of Natrons 15-42 (1948).

43. Article VIII permits "[a]ny Contracting Party" to call upon organs of the United Nations; Articie IX would allow only disputes "between the Contracting Parties" to be submitted to the International Court of Justice. The United States specifically asked that Article IX be worded as it is. The reason assigned was that such a phrase is necessary because "[o]nly States may be parties before the International Court." Economic and Social Council, Doc. No. E/623, at 27 (Jan. 30, 1948).

44. See U. N. Charter Articles 10-17, dealing with the functions of the Assembly; as to limitation of the Assembly's functions, see Ronissor, op. cit. supra note 15, at 59 (1946).

45. The powers and functions are set out in U. N. Charter Articles 62-6.

46. See Robinson, op. cit. supra note 15 , at 60 .

47. The Council may act when there are threats to or breaches of the peace, or acts of aggression. Its functions in this respect are defined in U. N. CHARTER Articles 39-51.

48. Paragraph 2 of the Article provides that "[i]f any party to a case fails to perform the obligations incumbent upon it under a judgment rendered by the Court, the other party may have recourse to the Security Council, which may, if it deems necessary, makc recommendations or decide upon measures to be taken to give effect to the judgment."

49. U. N. Charter Art. 39.

50. U. N. Charter Articles 39, 41, 42. 
tions ${ }^{51}$ permanently represented on the Council could resist coercion by casting a veto. ${ }^{52}$ For other nations, too, the likelihood always exists that no positive action would be taken; the Council might fail to obtain the required seven affirmative votes ${ }^{53}$ or, having a veto-free majority in agreement, the Council might not consider the genocide controversy cause for resort to war. ${ }^{\text {jo }}$ Only less drastic sanctions, such as diplomatic and economic pressure, are liliely.

Although existing international institutions provide no immediate positive sanctions against commission of the crime, the mere fact that a ratified treaty is in existence should have a deterrent effect on potential offenders. Under traditional international law, a State's unjustified unilateral repudiation of a treaty does not abrogate its obligations. ${ }^{\text {to }}$ Even though a group controlling a State were to modify its domestic law-to enable themselves to commit genocide with the endorsement of that law-the modifications would always be subject to the previously ratified Convention. The offenders could be tried under its provisions wherever and whenever an ad hoc tribunal, such as the Nürnberg Court, might get jurisdiction of their persons. ${ }^{\text {es }}$ Knowledge that constitutionally responsible rulers, public officials, and private individuals are equally susceptible to punishment, ${ }^{57}$ and that genocide is not to be considered a political crime for purposes of extradition, ${ }^{58}$ might well swing the weight needed to deter potential offenders from their initial step.

Future Establishment of a Permancnt World Criminal Court. Convention Article VI provides that persons charged with acts of genocide could be tried by national courts, or "by such international penal tribunal as may have jurisdiction with respect to those Contracting Parties which shall have accepted its jurisdiction." In a resolution passed after adoption of the Convention, the General Assembly requested the International Law Commission to "study the desirability and possibility of establishing an international judicial organ" having jurisdiction over the crime of genocide. ${ }^{50}$ Were a permanent world court

51. China, France, Russia, the United Kingdom, and the United States.

52. U. N. CeARTER Art. 27, $\{3$.

53. Ibid.

54. As it may under U. N. Chaster Art. 42. A situation is difficult to conceive in which any greater sanction than diplomatic and economic ostracization would be applied. Unless there were other underlying reasons creating circumstances which would independently operate to cause Council action, it seems very unlikely that military force would be used.

55. See 1 Oppenthens, International Law $\$ 18,493$, 534-9 (7th cd., Lauterpicht, 194S); Fenwick, Internatronal Law 430 and 450-6 (3d ed. 194S) ; and 2 Huts, I:iTERNATTONAL LAw $\$ \$ 33,546$ (2d ed. 1945). An interesting, theoretical comparison of private law contracts and international law treaties is found in Lnutensachr, Prwnte LAW SOURCes AND ANAlogies of Internatronal LaW $\$ \$ 69-793$ (1927).

Whatever doubts some commentators may have had respecting the principle were undoubtedly laid to rest by the Nürnberg opinion. See note 7 supro.

56. Convention Article IV, making individuals punishable for genocide, and the precedent of the Nürnberg trial, would be sufficient legal rationale.

57. Article IV.

58. Article VII.

59. Ratification of the present Convention does not bind contracting States to cnter 
established with authority to try individuals for specific international crimes, presumably the court would be given original jurisdiction over acts of genocide; it probably would not have appellate jurisdiction over national courts.

The establishment of a world criminal court, as yet only suggested, would, theoretically at least, offer far more competent international enforcement than the procedures which ratification of the present Convention will effect. It would bring relatively impartial judgments and opinion to a subject necessarily fraught with political implication; ${ }^{60}$ it would cause world enforcement procedures to be brought directly to bear on the individual offender, thus casting aside the protective mantle which the State now can afford him; and it would be a permanent reminder to potential offenders of the civilized world's resolve to apply positive criminal sanctions against them.

Enforcement of the court's mandates, however, would still be subject to many of the basic infirmities which beset all present international enforcement procedures. No government would willingly submit its leaders to international jurisdiction in those cases in which it would be unwilling to punish them under its own domestic law. A government would only do so as part of a peace settlement, as Germany submitted its leaders to trial at Nürnberg, and in this respect direct world criminal sanctions would remain comparable to those exercised by the victorious powers at the close of World War II. Successful foundation of world criminal jurisdiction must ultimately look to the creation of a world police force which could force removal of accused persons from national to international control. ${ }^{61}$

a subsequent treaty establishing the contemplated world criminal court. "[T] he matter of the international Court has not been settled definitely and is left essentially to future decisions of the United Nations." Article of Mr. Lemkin, printed as an extension of the remarks of Representative Celler of New York, in 95 CoNG. REC. App. A1270, A1271 (March 3, 1949). Professor Lemkin's position is fully supported by Article VI. See also Appendix, infra, Resolution Relating to the Study by the International Law Commission of the Question of an International Criminal Jurisdiction.

60. By its nature the crime is subject to identification with political issures. See, c.g, N.Y. Times, Feb. 14, 1949, p. 3, col. 8 (charge in U.S. Lithuanian Liberation Committee that Russia is committing genocide against Baltic peoples) ; N.Y. Times, Dec. 25, 1948, p. 2, col. 7 (Dutch charged with attempted genocide in Indonesian Republic).

61. Establishment of the court would, of course, limit the nebulous concept of sovereignty. To some, like Randolph of Virginia, to ask a State "to surrender part of her sovereignty, is like asking a lady to surrender part of her chastity." 2 BruCE, RANDoLPH 203-4 (1922). Others take a less reified view of the concept, seeing a contradiction in the term itself. Carrying the sovereignty premise to its logical conclusion unavoidably forces one into the position that "illimitable sovereignty" limits itself, for a fully sovereign State would be incapable of entering binding commitments. "[I]n this respect sovereignty, in the sense of capacity to act is not illimitable but seriously limited." Corwin, The Constitution and World Organization 5 (1944). See, also, Jessur, op. cit. supra note 42 , at 13 . A sophisticated view of sovereignty defines it as only the highest degree of formal authority within any group. LASSWELL \& KAPLAN, POWER AND SocIETy c. 8 (mimeographed; to be published in 1949). 


\section{The Convention and United States Law}

The United States is no stranger to the principle of collective action to eliminate international crimes. In the past America has entered or adhered to

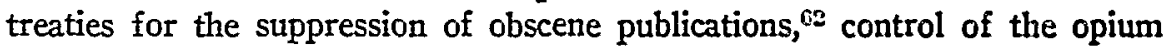
trade, ${ }^{63}$ and elimination of the slave trade ${ }^{04}$ and white slave traffic. ${ }^{\mathrm{cs}}$ America took active part in drafting the terms of the Genocide Convention and in promoting its adoption by the General Assembly. Other nations will justifiably expect early United States ratification.

Utilizing familiar legal institutions for enforcement and shaped largely in terms of Anglo-American legal theory, the Convention embodies traditional common-law concepts. It preserves the principle of territorial jurisdiction over criminal acts. ${ }^{66}$ Conspiracy, attempt, and complicity ${ }^{6 t}$ are familiar common-law crimes. In addition, the Convention definition of genocide itself meets traditional American concepts of a criminal act: ${ }^{68}$ to constitute the crime, an act must be coupled with specific "intent to destroy, in whole or in part, a national, ethnical, racial, or religious group, as such."

Under the Convention's definition of intent, the agreement would not greatly affect American institutional patterns. Where the requisite intent is laching, acts of violence might constitute murder or assault, but they could never constitute the crime as defined in the Convention. In a lynching, for example, while the participating individuals might be tried for murder, or for conspiracy to commit murder, they could never be tried for genocide unless the requisite intent accompanied commission of the act. ${ }^{70}$ Similarly, racial segregation could not constitute the crime, unless joined with intent to destroy the segregated group. Only segregation with purposes similar to those motivating Nazi use of concentration and labor camps would violate the treaty agreement. Drafted

62. U.S. TREaty SeR, No. 559 (Dep't State 1911) (entered).

63. E.g., U.S. Treaty Ser, No. 61 (Dep't State 1883) (entered); U.S. Treatr SER., No. 612 (Dep't State 1913) (entered).

67. U.S. TREATy SER., No. 778 (Dep't State 1926) (adherence with reservation); U.S. Treaty SER., No. 383 (Dep't State 1S90) (entered).

65. U.S. Treatr SeR, No. 496 (Dep't State 1S04) (adhered).

The United States has also entered a Miltilateral Treaty under which the contracting parties agreed to punish persons breaking or injuring submarine cables. U.S. TrEsT: SER., No. 380 (Dep't State 1884).

66. See note 37 supra. The United States has traditionally insisted upon the principle of territorial criminal jurisdiction at international law. Sce Custing's Cosc, 2 MOORE, Digest OF INTERNational LAW $\$ 201$ (1906).

67. Punishable under Article III.

68. For theoretical analysis see Hali, Princtples of Crramiar. Law \&-1S (1947).

69. Article II. The United States first suggested addition of an intent element to the crime. Economic and Sacial Council, Doc. No. E/623, at 11.

The gist of the offense as defined lies in the specific intent required. Specific intent must be proved; it cannot be presumed. See, c.g., Simpson v. State, 81 Fla. 292, 87 So. 920 (1921) ; State v. Schaefer, 35 11ont. 217, \&S Pac. 792 (1907).

70. This matter is discussed by Professor Lemlin in his article, cited note 59 sesfro, at A1271. 
as the Convention is, its application in America would be largely limited to suppression of future "Brown Shirt" movements, if and when such groups were to employ genocidal measures in attaining their ends.

The Constitution and the Convention. Under the Convention, the United States undertakes to enact, in accordance with its Constitution, legislation necessary to give effect to the Convention and to provide penalties for its violation. ${ }^{71}$ Ample authority exists for the United States to enter a convention of this kind, and for Congress to enact the necessary penal legislation.

Courts have traditionally considered the treaty power ${ }^{2 \mathrm{a}}$ a distinct, substantive grant of power to the Federal Government. ${ }^{73}$ No case has ever held an exercise of the treaty power excessive. ${ }^{74}$ Discussing possible limitations on the power, the Supreme Court has suggested in occasional dicta that only treaties abrogating the basic constitutional guarantees would be struck down. ${ }^{76}$

71. Article V. Only the Federal Government would be required to enact legislation under the Convention.

72. The provisions of the Constitution relating to the treaty power are: Art. II, $\$ 2$, giving the President power to make treaties, by and with the consent of the Senate; Art. VI, providing that the Constitution, laws, and "all treaties made, or which shall be made, under the authority of the United States shall be the supreme law of the land"; under Art. III, $\$ 2$, the Supreme Court has jurisdiction over all cases arising under the "Constitution, the laws of the United States, and the treaties made, or which shall be made, under their authority." Art. I, $\S 10$ forbids the States the exercise of any treaty power.

73. Striking illustration of this principle is presented by the legal history of the Federal Government's attempts to regulate the killing of migratory fowl. In 1913 Congress passed an act under the commerce clause regulating the destruction of migratory birds. Lower Federal courts held the act unconstitutional in United States v. McCullagh, 221 Fed. 288 (D.C. Kan. 1915), and United States v. Shauver, 214 Fed. 154 (E.D. Ark. 1914). In 1916 the United States entered a treaty with Great Britain, under the terms of which Canada and the United States undertook to protect migratory fowl. When, in 1918, Congress enacted stringent regulation under the treaty, the act was upheld under the Federal treaty power, Missouri v. Holland, 252 U.S. 416 (1920).

74. 2 HYDE, INTERNATTONAL LAW $\$ 502$ (2d ed. 1945).

75. Note, 33 Harv. L. Rev. 281 (1919). Geofroy v. Riggs, 133 U.S. 258, 267 (1889) (treaty protecting French-owned real estate in "United States upheld): "The treaty" power, as expressed in the Constitution, is in terms unlimited except by those restraints which are found in that instrument against the action of the government or of its departments, and those arising from the nature of the government itself and of that of the States. It would not be contended that it extends so far as to authorize what the Constitution forbids, or a change in the character of the government or in that of one of the States, or a cession of any portion of the territory of the latter without its consent. . . . But with these exceptions, it is not perceived that there is any limit to the questions which can be adjusted touching any matter which is properly the subject of negotiation with a forcign country."

These dicta are usually cited by commentators as expressive of the kind of limitations to which the treaty power is subject. Compare dicta in the following cases, in which the Court, while recognizing the possibility of constitutional limits, emphasizes the broad scope of the treaty power: Asakura v. Seattle, 265 U.S. 332, 341 (1923): "The treatymaking power of the United States is not limited by any express provision of the Constitution, and, though it does not extend so far as to authorize what the Constitution forbids, it does extend to all proper. subjects of negotiation between our government and 
It has even been urged that the treaty power is not subject to the same restrictions as are the acts of Congress. ${ }^{76}$ While this suggestion is usually considered extreme, it is generally agreed that the power extends to all matters of national concern which require international measures of cooperation. ${ }^{77}$

Congressional authority to enact enforcing legislation is co-estensive with the treaty power. ${ }^{78}$ Legislative power under a treaty does not depend upon any other positive grant of authority, but is considered to be a separate constitu-

other nations." Holden v. Joy, 17 Wall. 211, 243 (U.S. 1872): "[I]nasmuch as the [treaty] power is given, in general terms, without any description of the objects intended to be embraced within its scope, it must be assumed that the framers of the Constitution intended that it should extend to all those objects which in the intercourse of nations had usually been regarded as the proper subjects of negotiation and treaty, if nut inconsistent with the nature of our government ..." See also Ist re Ross, 140 U.S. 453, 463 (1891); Hauenstein v. Lynham, 100 U.S. 483, 48S-90 (1879); Chirac v. Chirac, 2 Wheat. 259, 271 (U.S. 1817) ; and Ware v. Hyiton, 3 Dall. 199, 236-7, 281 (U.S. 1796). In cases not involving treaties-cases in which the Court has been considering the federal government's power over foreign affairs-the Court's language has been even more sweepingly favorable to federal power: United States v. Pink, 315 U.S. 203, 230-3 (1942); and United States v. Belmont, 301 U.S. 324, 331 (1937). See, generally, Feidler \& Dwan, The Extesnt of the Treaty-Making Poucr, 28 GEo. L. J. 184 (1939).

76. "Acts of Congress are the supreme law of the land only when made in pursuance of the Constitution, while treaties are declared to be so when made under the authority of the United States. It is open to question whether the authority of the United States means more than the formal acts prescribed to make the convention. We do not mean to imply that there are no qualifications to the treaty-malsing power; but they must be ascertained in a different way. It is obvious that there may be matters of the sharpest exigency for the national well-being that an act of Congress could not deal with but that a treaty followed by such an act could, and it is not lightly to be assumed that, in matters requiring national action, 'a power which must belong to and somewhere reside in every civilized government' is not to be found." Misssouri v. Holland, 252 U.S. 416,433 (1920).

77. E.g., Feidler \& Dwan, supra note 75, at 193-7; MrcDougal \& Lans, Trcalics and Congressional-Executiz'e or Presidcntial Agrecments: Intcrelangcoble Instruntonts of National Policy, 54 YaLe L.J. 181, 255-61 (1945). See cases cited note 75 sisfra.

78. Missouri v. Holland, 252 U.S. 416 (1920). This principle was recognized by commentators before Holland was decided. See, c.g., Anderson, Extent and Limilations of the Treaty Poz'er, 1 Axr. J. Inv'L L. 636, 657 (1907). Even in the absence of tresty; the Constitution gives Congress power "to define and punish piracies and felonies committed on the high seas and offenses against the law of nations." U. S. Co:vs. Art. I, S S. Hence, even without treaty, there seems no reason that Congress could not define and punish this crime.

Mforeover, under a doctrine of inherent powers it is widely accepted that Congress derives power also from the mere fact of United States sovereignty. AIcDougal \& Ians, supra note 77, at 255-61. In United States v. Curtiss-Wright Export Corp., 299 U.S. 304, 318 (1936), the Court said: "It results that the investment of the federal government with the powers of external sovereignty did not depend upon the affirmative grants of the Constitution. The powers to declare and wage war, to conclude peace, to malse treaties, to maintain diplomatic relations with other sovereignties, if they had never been mentioned in the Constitution, would have vested in the federal government as nccessary concomitants of nationality. ... As a member of the family of nations, the right and power of the United States in that field are equal to the right and power of other members of the international family. Otherwise the United States is not completely sovereign. 
tional grant, sufficient in extent to enable the Congress to fulfill treaty commitments. ${ }^{79}$

Extradition Under the Convention. Extradition provisions of the Convention would cause no dislocation of present American extradition policies. The Convention permits extradition only in accordance with laws and treaties presently existing. ${ }^{80}$ The United States does not favor extradition of political offenders, ${ }^{81}$ but its position does not conflict with the Convention's extradition provision. Genocide, in effect mass-destruction, should not be considered a political crime for purposes of extradition. No political activity can justify the crime as defined. American procedures, moreover, would prevent extradition of any person against whom fabricated charges of genocide were made by a foreign government. Procedural safeguards before commitment prior to extradition are similar to those required in usual preliminary commitment exami-

The power to acquire territory by discovery and occupation. . . , the power to expel undesirable aliens ...., the power to make such international agreements as do not constitute treaties in the constitutional sense. . ., none of which is expressly affirmed by the Constitution, nevertheless exist as inherently inseparable from the conception of nationality. This the Court recognized, and in each of the cases cited found the warrant for its conclusions not in the provisions of the Constitution, but in the law of nations." And see Fong Yue Ting v. United States, 149 U.S. 698, 711-2 (1893) (power as sovereign nation to exclude aliens from United States).

Commentators have urged the same view. See Conwris, op. cit. stupra note 61, at 19: "[T] he power of the National Government in the field of international relationship is not a complexus of particular enumerated powers, but is an inherent pozter, one which is attributed to the National Government on the ground solely of its belonging to the American People as a sovereign political entity at International Law." See also Crundatu, Treaties, Their Making and Enforcensent $\$ 110$ (2d ed. 1916); Williams, Inherent Sovereign Powers of the Federal Govermment, 6 U.S.C. SELdON SoC. YeAR Book 1 (1942).

79. Missouri v. Holland, 252 U.S. 416 (1920). Borchard, Treaty-Making Pozer as Support for Federal Legislation, 29 Y ALE L.J. 445 (1920).

The Tenth Amendment does not limit powers expressly granted the Federal Government. The contention that the Amendment operates as an "independent limiting force" upon the treaty power was considered at length and rejected in Missouri v. Holland, supra. In recent years the Amendment has met a similar fate when offered to defeat excrcise of other Federal powers. Compare, e.g., Ashton v. Cameron, 298 U.S. 513 (1936), zvith United States v. Bekins, 304 U.S. 27 (1938) (bankruptcy power); as to the commerce power, compare Hammer v. Dagenhart, 247 U.S. 251 (1918), with United States v. Darby Lumber Co., 312 U.S. 100 (1941), in which the Court declared, "The amendment states but a truism that all is retained which has not been surrendered." Id. at 124. See also United States v. Sprague, 282 U.S. 716, 733-4 (1931): "The Tenth Amendment . . . added nothing to the ... [Constitution] as originally ratified and has no limited and special operation, as is contended." See Feller, The Tenth Amcndment Retircs, 27 A. B. A. J. 223 (1941). For an acute analysis of the constitutional position of the states under the treaty power, see Corwin, National Suprearacy; TreatY Power vs. State POWER (1913).

80. Article VII. In the absence of treaty, the United States refuses to surrender fugitive criminals. Terlinden v. Ames, 184 U.S. 270, 289 (1902) ; United States v. Rat1scher, 119 U.S. 407 (1886). This accords with the general rule of international law. 1 OPPENHEIM, INTERNATIONAL LAW \$327 (7th ed., Lauterpacht, 1948).

81. See general discussion in 2 Hyde, International LAw $\$ \$ 315-17$ (2d ed. 1945). 
nations. ${ }^{52}$ Extradition of American nationals for commission of the crime abroad presents no difficulties. The United States has long talien the lead in advocating mutual rendition of nationals, ${ }^{83}$ and does not even object to the extradition of American citizens from one foreign state to another. ${ }^{81}$

The Proposed World Criminal Court. Acceptance of the present Convention does not make mandatory eventual American acceptance of a subsequent treaty establishing an international criminal court having original jurisdiction over the crime of genocide. ${ }^{85}$ Ratification will only mean acceptance of the jurisdiction of the International Court of Justice over disputes arising from the interpretation, application or fulfillment of the Convention. On other occasions the United States has submitted to international supervision of this kind, although with some reservations. ${ }^{86}$

But the fact that the Convention does contemplate a world criminal court suggests that the question of the court's constitutionality may eventually have to be answered. It is an open question whether the United States could constitutionally accede to a treaty giving an international court jurisdiction of criminal acts committed within its territorial limits.

Appellate jurisdiction superior to the Supreme Court apparently cannot be conferred. ${ }^{87}$ Presumably the proposed world court will not be given this juris-

82. 18 U.S.C. $\$ \$ 3181-95$ (effective Sept. 1, 1948). See Benson v. MedIahon, 137 U.S. 457, 463 (1888); Ist re Ezeta, 62 Fed. 972 , 982 (N.D. CaL 1S94).

83. The history of our policy is found in Rafuse, The Extradition of Nationals in 24 Untv. of IrL. Studies in the Soc. Scr. 1-30 (1939). See also Hyde, Notes on the Extradition Treaties of the United States, S Axr. J. INT'L L. 487 (1914).

84. 1 MoORE, Extradition $\$ 143$ (1891).

85. See note 59 supra.

86. See 1 Malioy, Treaties 549 (1910) (treaty with France). Mforeover, the United States has already submitted itself to compulsory International Court of Justice jurisdiction, with reservation of "disputes with regard to matters which are essentially within the domestic jurisdiction of the United States, as determined by the United States." For debate on the reservation see 92 CoNG. REc. 10683-97 (1946), and for incisive articles condemning it see Preuss, Questions Resulting frosis the Comally Amendincnt, 32 A. B. A. J. 660 (1946), and Jutrisdiction of World Court: Rcasons for Urging a New Americain Declaration, 33 A. B. A. J. 430 (1947).

Were a reservation of this kind made in ratifying the Genocide Convention, the effectiveness of Article IX would be drastically reduced. Unilateral determination of what is or is not a genocide issue "within domestic jurisdiction," would, in effect, do away with International Court jurisdiction over disputes arising from the interpretation, application, or fulfillment of the Convention. Genocide is a matter of international concern and should not be treated as falling solely within domestic jurisdietion of any State. The United States recognized genocide's international import when, in 1902, it prutested Roumania's domestic treatment of Roumanian Jews on the ground that such discrimination caused large numbers of the oppressed to emigrate and be thrown upen the charity of the United States. U. S. ForeIGN ReL.: 1902 at 42 (Dep't State 1903). A copy of the protest was sent to Turkey. Id. at 1048. Genocide also has international repercussions of other than a financial nature. Where national religious groups are attacled, the issues become of international concern because most religions transcend national boundaries.

87. The State Department, at least, made this objection to the International Prize Court constituted in the Hague Convention of 1907. U. S. Forerg: Ret. 1911 at $24 S$ 
diction. ${ }^{88}$ And unless such appellate power is intended by the United Nations, this question is not presented. But certainly the court would be given original jurisdiction. The issue then would be whether such a court might constitutionally be granted concurrent jurisdiction with the Supreme Court. Article III of the Constitution vests "[ $t]$ he judicial power of the United States . . . in one Supreme Court," and extends the power "to all cases in law and equity, arising under this Constitution, the laws of the United States, and the treaties made, or which shall be made, under their authority. . .." This provision does not preclude Congress from depriving the Supreme Court of jurisdiction over a given class of cases. ${ }^{80}$ But it is debatable whether Congress, despite support of the supremacy clause ${ }^{90}$ and Congressional power to "define and punish . . . offenses against the law of nations,"01 could grant original jurisdiction to the contemplated court.

The issue is de novo. No case dicta give intimation of the Supreme Court's probable position were the question presented. Should the Court refuse to uphold a grant of original jurisdiction to a world court, proponents of the contemplated tribunal could succeed only by the difficult process of constitutional amendment.92

\section{CONCLUSION}

The Genocide Convention is the world's first attempt to eliminate planned destruction of human groups and to answer the Nürnberg challenge. Similar to treaties for suppression of piracy and slave traffic in that it defines an international crime and binds signatory nations to apprehend and punish offenders, the Convention is unlike them in that it provides some measure of United Nations enforcement and contemplates future establishment of a world criminal court having original jurisdiction over the offense. In contemplating eventual international court jurisdiction over individuals in time of peace, the genocide treaty introduces a completely new international law concept. Nothing in existing international institutions is comparable. While the Convention would

(Dep't State 1918). There is no case on the point.

The suggestion has been made that the problem could be solved by allowing direct appeal from the lower federal courts to international courts. Wright, Trcatics and the Constitutional Separation of Powers in the United States, 12 Axr. J. INT'L L. 64, 86-8 (1918).

88. The wording of Article VI indicates an intention to give only original jurisdiction. The Article reads, "Persons charged ... shall be tried by a competent tribunal of the State in the territory of which the act was committed, or by such international penal tribunal as may have jurisdiction. ..." The international court would presumably have original jurisdiction.

89. In Ex parte McCardle, 7 Wall. 506 (U.S. 1868), a special statute was passed taking jurisdiction from the Supreme Court-even after the case had been argued.

90. U. S. Const. Art. VI.

91. U. S. Const. Art. $1, \S 8$.

92. In the meantime, any doubts could be resolved by reservations in ratification. For the substantive effect of a reservation, see Sanders, Reservations to Multilatcral Treaties Made in the Act of Ratification or Adherence, 33 AMr. J. INT'L L. 488 (1939); as to procedural steps, see Miller, Reservations to Treaties (1919). 
lack support from the power of formally constituted international government, it would have behind it the collective force of signatory nations. Compared with established standards of national penal enforcement, the Convention might seem an instrument of pioneer justice; but these are pioneer days in world law. Perhaps this is the kind of quasi-law from which effective world law may be expected eventually to develop.

\author{
APPENDIX \\ CONVENTION ON THE PREVENTION AND PUNISHMIENT OF THE \\ The Contracting Parties, \\ CRIME OF GENOCIDE \\ Having considered the declaration made by the General Assembly of the United Na- \\ tions in its resolution 96 (I) dated 11 December 1946 that genocide is a crime under in- \\ ternational law, contrary to the spirit and aims of the United Nations and condemned by \\ the civilized world; \\ Recognizing that at all periods of history genocide has inflicted great losses on hu- \\ manity; and \\ Being convinced that, in order to liberate manlind from such an odious scourge, in- \\ ternational co-operation is required; \\ Hereby agree as hereinafter provided:
}

\title{
ARTICLE I
}

The Contracting Parties confirm that genocide, whether committed in time of peace or in time of war, is a crime under international law which they undertalie to prevent and to punish.

\section{ARTICLE II}

In the present Convention, genocide means any of the following acts committed with intent to destroy, in whole or in part, a national, ethnical, racial or religious group, as such:

(a) Killing members of the group;

(b) Causing serious bodily or mental harm to members of the group;

(c) Deliberately inflicting on the group conditions of life calculated to bring about its physical destruction in whole or in part;

(d) Imposing measures intended to prevent births within the group;

(e) Forcibly transferring children of the group to another group.

The following acts shall be punishable:

\section{ARTICLE III}

(a) Genocide;

(b) Conspiracy to commit genocide;

(c) Direct and public incitement to commit genocide;

(d) Attempt to commit genocide;

(e) Complicity in genocide.

\section{ARTICLE IV}

Persons committing genocide or any of the other acts enumerated in article III shall be punished, whether they are constitutionally responsible rulers, public officials or private individuals. 


\section{ARTICLE V}

The Contracting Parties undertake to enact, in accordance with their respective Constitutions, the necessary legislation to give effect to the provisions of the present Convention and, in particular, to provide effective penalties for persons guilty of genocide or any of the other acts enumerated in article III.

\section{ARTICLE VI}

Persons charged with genocide or any of the other acts enumerated in article III shall be tried by a competent tribunal of the State in the territory of which the act was committed, or by such international penal tribunal as may have jurisdiction with respect to those Contracting Parties which shall have accepted its jurisdiction.

\section{ARTICLE VII}

Genocide and the other acts enumerated in article III shall not be considered as political crimes for the purpose of extradition.

The Contracting Parties pledge themselves in such cases to grant extradition in accordance with their laws and treaties in force.

\section{ARTICLE VIII}

Any Contracting Party may call upon the competent organs of the United Nations to take such action under the Charter of the United Nations as they consider appropriate for the prevention and suppression of acts of genocide or any of the other acts cnumerated in article III.

\section{ARTICLE IX}

Disputes between the Contracting Parties relating to the interpretation, application or fulfilment of the present Convention, including those relating to the responsibility of a State for genocide or any of the other acts enumerated in article III, shall be submitted to the International Court of Justice at the request of any of the parties to the dispute.

\section{ARTICLE X}

The present Convention, of which the Chinese, English, French, Russian and Spanish texts are equally authentic, shall bear the date of

\section{ARTICLE XI}

The present Convention shall be open until 31 December 1949 for signature on behalf of any Member of the United Nations and of any non-member State to which an invitation to sign has been addressed by the General Assembly.

The present Convention shall be ratified, and the instruments of ratification shall be deposited with the Secretary General of the United Nations.

After 1 January 1950 the present Convention may be acceded to on behalf of any Member of the United Nations and of any non-member State which has received an invitation as aforesaid.

Instruments of accession shall be deposited with the Secretary-General of the United Nations.

\section{ARTICLE XII}

Any Contracting Party may at any time, by notification addressed to the SecretaryGeneral of the United Nations, extend the application of the present Convention to all or any of the territories for the conduct of whose foreign relations that Contracting Party is responsible.

\section{ARTICLE XIII}

On the day when the first twenty instruments of ratification or accession have been deposited, the Secretary-General shall draw up a proces-verbal and transmit a copy of 
it to each Member of the United Nations and to each of the non-member States contemplated in article XI.

The present Convention shall come into force on the ninetieth day following the date of deposit of the twentieth instrument of ratification or accession.

Any ratification or accession effected subsequent to the latter date shall become efieetive on the ninetieth day following the deposit of the instrument of ratification or accession.

\section{ARTICLE XIV}

The present Convention shall remain in effect for a period of ten years as from the date of its coming into force.

It shall thereafter remain in force for successive periods of five years for such Contracting Parties as have not denounced it at least six months before the expiration of the current period.

Denunciation shall be effected by a written notification addressed to the Secretary-General of the United Nations.

\section{ARTICLE XV}

If, as a result of denunciations, the number of Parties to the present Convention should become less than sixteen, the Convention shall cease to be in force as from the date on which the last of these denunciations shall become effective.

\section{ARTICLE XVI}

A request for the revision of the present Convention may be made at any time by any Contracting Party by means of a notification in writing addressed to the Secretary-General.

The General Assembly shall decide upon the steps, if any, to be taken in respect of such request.

\section{ARTICLE XVII}

The Secretary-General of the United Nations shall notify all Members of the United Nations and the non-member States contemplated in article XI of the following:

(a) Signatures, ratifications and accessions received in accordance with article XI;

(b) Notifications received in accordance with article XII;

(c) The date upon which the present Convention comes into force in accordance with article XIII;

(d) Denunciations received in accordance with article XIV;

(e) The abrogation of the Convention in accordance with article XV;

(f) Notifications received in accordance with article XVI.

\section{ARTICLE XVIII}

The original of the present Convention shall be deposited in the archives of the United Nations.

A certified copy of the Convention shall be transmitted to all Alembers of the United Nations and to the non-member States contemplated in article XI.

\section{ARTICLE XIX}

The present Convention shall be registered by the Secretary-General of the United Nations on the date of its coming into force. 
RESOLUTION RELATING TO THE STUDY BY THE INTERNATIONAL LAW COMMISSION OF THE QUESTION OF AN INTERNATIONAL CRIMINAL JURISDICTION

The General Assearbly,

Considering that the discussion of the Convention on the Prevention and Punishment of the Crime of Genocide has raised the question of the desirability and possibility of having persons charged with genocide tried by a competent international triburial,

Considering that, in the course of development of the international community, there will be an increasing need of an international judicial organ for the trial of certain crimes under international law,

Invites the International Law Commission to study the desirability and possibility of establishing an international judicial organ for the trial of persons charged with genocide or other crimes over which jurisdiction will be conferred upon that organ by international conventions;

Requests the International Law Commission in carrying out this task to pay attention to the possibility of establishing a Criminal Chamber of the International Court of Justice.

\section{RESOLUTION RELATING TO THE APPLICATION OF THE CONVENTION ON THE PREVENTION AND PUNISHMENT OF THE CRIME OF GENOCIDE WITH RESPECT TO DEPENDENT TERRITORIES}

The General Assembly recommends that Parties to the Convention on the Preven. tion and Punishment of the Crime of Genocide which administer dependent territorics, should take such measures as are necessary and feasible to enable the provisions of the Convention to be extended to those territories as soon as possible. 